\title{
Paradigm not procedure: current challenges to police cultural incorporation of human rights in England and Wales
}

\author{
Clive Harfield ${ }^{*}$
}

\section{Introduction}

It is reasonable to ask, a decade on from the enactment of the Human Rights Act 1998 [HRA] in the United Kingdom, to what extent can policing in England and Wales now be characterised as embracing human rights? ${ }^{1}$ Human rights permeate English policing as reflected in various accountability mechanisms but whether they can truly be said to be the cultural norm is a different matter. Significant challenges remain in establishing such a culture, some of which lie outside the police service. Key questions illustrate the issues and this paper considers them from the context of covert investigation. The focus of covert investigation is adopted here partly for reasons of space - the various ways in which policing engages with human rights warrants lengthier consideration than is possible in a single paper - but primarily because the enactment of the HRA prompted consequential statutory innovation to ensure covert investigation was HRA-compliant. Covert investigation, considered essential in tackling and prosecuting the prevailing political and national security concerns of terrorism and organized crime, thus has become by default rather than design the context within which British discourse about human rights and policing usually takes place. This paper, by adopting the same focus and constrained parameters, of course does nothing to address the lacuna in the debate but the

\footnotetext{
* Dr Clive Harfield is an Associate Professor of Criminal Law at the University of Wollongong, NSW, where he is also a Research Associate in the Centre for Transnational Crime Prevention.

${ }^{1}$ The United Kingdom of Great Britain and Northern Ireland comprises three criminal jurisdictions: Northern Ireland; Scotland; and, jointly, England and Wales. The HRA has general applicability in all three jurisdictions. Because the three jurisdictions have specific characteristics and measures, this paper focuses only on the largest of the three, England and Wales. For the purposes of brevity, subsequent references to English and England should be taken to include Welsh and Wales.
} 
legislative responses to the need to ensure covert investigation rights, as will be argued below, have characterised the ongoing discussion in ways that have given rise to particular organizational cultural perceptions within the police service, creating their own challenges which may colour any wider debate around human rights and policing. Whilst acknowledging the wider debate that needs to take place, this paper addresses the immediate challenges which appear to threaten full acceptance of human rights protection within policing culture.

\section{What are human rights?}

The preamble makes explicit the purpose of the HRA: it is 'an Act to give further effect to rights and freedoms guaranteed under the European Convention on Human Rights' [ECHR]. ${ }^{2}$ From this pedigree of international law, domestic effect is given to Articles 2-12 and 14 of the ECHR, Articles 1-3 of the First Protocol and Article 1 of the Thirteenth Protocol, as read with Articles 16-18 of the Convention (see Table 1).

Table 1 - ECHR provisions given domestic effect by the HRA 1998, s.1

- The right to life (ECHR Art.2)

- The prohibition of torture (Art.3)

- The prohibition of slavery and forced labour (Art.4)

- The right to liberty and security (Art.5)

- The right to fair trial (Art.6)

- The right to no punishment without law (Art.7)

- The right to respect for private and family life (Art.8)

- The right to freedom of thought, conscience and religion (Art.9)

- The right to freedom of expression (Art.10)

- The right to freedom of assembly and association (Art.11)

- The right to marry (Art.12)

- The prohibition of discrimination (Art.14)

- Protection of property (Protocol 1, Art.1)

- The right to education (Protocol 1, Art.2)

- The right to free elections (Protocol 1, Art.3)

- Abolition of the death penalty (Protocol 13, Art.1)

\footnotetext{
2 The full title of the Council of Europe instrument is The European Convention for the Protection of Human Rights and Fundamental Freedoms, done at Rome $4^{\text {th }}$ November 1950, European Treaty Series No.5. (Hereafter ECHR).
} 
It is unlawful for public authorities to act in ways incompatible with protected rights. ${ }^{3}$ Not all rights are absolute: some are qualified. Subject to statutory authority, in certain circumstances and in accordance with the principles of legitimacy, necessity and proportionality, state authorities may interfere with qualified rights. The drafting of individual articles indicates which are absolute and which are qualified.

Of particular relevance to police covert investigation in this regard is Article 8(1): 'Everyone has the right to respect for his private and family life, his home and his correspondence'. Article 1 of the First Protocol supplements this: 'Every natural and legal person is entitled to the peaceful enjoyment of his possessions'. These assertions are qualified as follows.

There shall be no interference by a public authority with the exercise of this right except such as is in accordance with the law and is necessary in a democratic society in the interests of national security, public safety or the economic well-being of the country, for the prevention of disorder or crime, for the protection of health and morals, or for the protection of the rights and freedoms of others. ${ }^{4}$

Article 1, Protocol 1, ECHR is similarly qualified:

No one shall be deprived of his possessions except in the public interest and subject to the conditions provided for by law and by the general principles of international law.

A product of its time, this framework is consistent with the view prevailing at the end of the Second World War that human rights protection meant protection of the individual citizen from abuse of state power. Article 8, and its qualifications, illustrates this formulation and the means by which a statutory balance is effected to allow state authorities properly to investigate infringements against law.

\footnotetext{
${ }^{3}$ Human Rights Act 1998 (UK) s 6.
}

${ }^{4}$ ECHR art 8 (2). 
This construction is latterly seen as unduly narrow and restrictive. ${ }^{5}$ Rights conceptualization is expanding beyond protection from state abuse to include positive entitlements to basic standards of living; to the guarantee of civil and political rights; to the provision of social and economic rights; and to the protection from the adverse impact of climate change. ${ }^{6}$ Increasingly a concept of victims' rights is articulated. Former UK Prime Minister Tony Blair pursued a policy objective of rebalancing the criminal justice system in favour of victims because prevailing public perception was that human rights protected the accused not from abuse of state power but from effective investigation and prosecution. ${ }^{7}$ Academic and policy consideration is now being given to the issue of horizontality; the idea that individual rights deserve actionable protection from interference by other private citizens or non-state actors: a further extension of the original concept. ${ }^{8}$

At the same time as the conception of human rights is broadening, the problematic juxtaposition of the rights of the individual with the rights of the wider community has been thrown into sharp focus in numerous jurisdictions as a consequence of national and international responses to terrorism that is co-ordinated on or, perhaps more accurately, inspired to operate on a global scale. ${ }^{9}$ In the British context, recourse to enhanced covert and coercive law enforcement powers arguably will metamorphose the premise of policing with the community into a philosophy of policing of the community, bringing with it a consequential erosion of human rights protection: 'the loss of liberty is the price we pay for freedom'. ${ }^{10}$

\footnotetext{
5 Sandra Fredman, Human Rights Transformed: Positive Rights and Positive Duties (2008, Oxford University Press, Oxford).

6 Henry Steiner, Philip Alston and Ryan Goodman International Human Rights in Context: Law, Politics, Morals (2008, Oxford University Press, Oxford), chapters 3, 4 and 16.

7 Paul Rock, Constructing Victims' Rights: the Home Office, New Labour and Victims (2004, Oxford University Press, Oxford); Prime Minister's Strategy Unit, Building On Progress: Security, Crime and Justice, (2007, PMSU, London). Whether such a perception, fuelled in the popular media, is justified is an important issue beyond the scope of this paper.

${ }^{8}$ Sir Stephen Sedley, 'The rocks or the open sea: where is the Human Rights Act heading?' (2005) 32 Journal of Law and Society 3; Steiner et al, $\mathrm{n} 7$.

9 Philip Heymann 'Civil liberties and human rights in the aftermath of September 11' (2002) 25 Harvard Journal of Law and Public Policy 441; Agnes Chong and Waleed Kadous 'Freedom for security: necessary evil or Faustian pact?' (2005) 28 UNSW Law Journal 887; Sedley above n 9; Steiner et al, above n 7; Leonard Weinberg, William Eubank and Elizabeth Francis 'The cost of terrorism: the relationship between international terrorism and democratic governance' (2008) 20 Terrorism and Political Violence 257.

10 Alan Bennett, The History Boys (2004, Faber, London) 3. Policing with the community is a paradigm that has evolved over time. Its origins can be traced to the Nine Principles of Policing articulated by Sir Robert Peel when creating the Metropolitan Police Service in London in 1829; see for instance John Grieve, Clive Harfield and Allyson MacVean, Policing (2007, Sage, London) 36-7. Peel posited his constables firmly as members of the community they served. They policed with the community and by the consent of the community recognising that successful policing could only be achieved with the "willing co-operation" of the community (Principle 3). Nearly 200 years later the
} 
The rights construction considered here is that within which the English police operate - the HRA and associated English legislation. ${ }^{11}$ But even the understanding of this framework has evolved since it was first enacted. Originally envisaged within the policing and investigation management context of preventing miscarriages of justice, as greater familiarity with the HRA and its implications is achieved the focus has widened from protecting merely the rights of investigation subjects to an understanding that the rights of third parties and those employed by the state authorities undertaking the investigation must also be respected: that the state and its agencies have a positive duty of care in certain circumstances. ${ }^{12}$

Thus at the start of the twenty-first century, English policing practice operates within a defined statutory framework for human rights which embodies notions of rights now fifty years old, whilst prevailing discourse has developed thinking considerably, with the possible consequence that debates about human rights and policing may be confused if interlocutors have different perceptions and understanding of the issues.

Home Office, defining policing by consent narrowly as policing by acquiescence, is seeking to revitalise the notion of policing with the community by engaging active and meaningful community debate about policing priorities: Home Office, Building Communities, Beating Crime: A Better Police Service for the $21^{\text {st }}$ Century (2004, Cm 6360, TSO, London) paragraph 1.32.

${ }_{11}$ Namely the Police Act 1997 (Part III) and the Regulation of Investigatory Powers Act 2000.

12 See for instance Roger Billingsley 'Duty of care for informers' (2005) 78 The Police Journal 209. 


\section{What is policing?}

If the debate about human rights is a work in progress, albeit with policing and human rights firmly anchored by the historical framework articulated in the HRA, the on-going debate about what is policing is no less vigorous. ${ }^{13}$ English policing holds dear the philosophy of policing by consent: police legitimacy being as dependent upon the consent and support of the public as it is upon statutory empowerment. ${ }^{14}$ It is a philosophy expressed through the requirement for public consultation about policing priorities. ${ }^{15}$ The extent to which it is practical as well as aspirational is debatable; the extent to which consensus is derived from consent even more so.

Since 1993 there have been thirteen assorted reviews, Green Papers and White Papers about the purpose and practice of policing in England and eight major pieces of legislation reconfiguring the purpose or framework (not including the HRA and consequential legislation or specific public inquiries into individual investigations or incidents: see Table 2). The last fifteen years of English policing have been years of constant debate and frequent significant change. ${ }^{16}$ Some commentators have observed that the police service has become a political football. ${ }^{17}$ The President of the Association of Chief Police Officers called in 2007 for 'a fundamental review' of policing and the latest government-led fundamental review and consultation is underway at time of writing. ${ }^{18}$ In Parliament the Home Affairs Committee has called for a royal commission on policing. ${ }^{19}$

\footnotetext{
${ }_{14}^{13}$ Stephen Savage, Police Reform: Forces for Change (2007, Oxford University Press, Oxford).

14 Ian Loader and Aogán Mulcahy, Policing and the Condition of England: Memory, Politics and Culture (2003, Oxford University Press, Oxford).

${ }_{15}$ Clive Harfield 'Consent, consensus or the management of dissent? Challenges to community consultation in a new policing environment' (1997) 7 Policing and Society 271; T. Jones 'The governance and accountability of policing' in Tim Newburn (ed), Handbook of Policing (2003, Willan, Culhompton).

${ }^{16}$ In Northern Ireland, a separate jurisdiction within the UK, radical reform of policing and the police service was a significant element within the overall peace process after years of sectarian conflict that saw the army deployed to assist civilian policing in securing public order. For the policing issues see Independent Commission on Policing for Northern Ireland, A New Beginning: Policing in Northern Ireland. Belfast, (The Patten Report) (1999).

17 Peter Waddington, 'Political axe hangs over policing' Police Review, London, $24^{\text {th }}$ October 2008, 16-17.

18 Association of Chief Police Officers of England and Wales, Press Release 67/07, 19 $9^{\text {th }}$ June 2007; Home Office From the Neighbourhood to the National: Policing our Communities Together (2008, TSO, London).

${ }^{19}$ Home Affairs Committee, A Surveillance Society? (2008, TSO, London)
} 
Table 2 - Reviews and laws in relation to the purpose of policing in England 1993-2008

\section{Legislation}

Police and Magistrates Court Act 1994

Police Act 1996

Police Act 1997

Crime and Disorder Act 1998

Criminal Justice and Police Act 2001

Police Reform Act 2002

Serious Organised Crime and Police Act 2005

Criminal Justice and Police Act 2006

\section{Reviews, in chronological order}

Sir Patrick Sheehy, Inquiry into Police Responsibilities and Rewards. (1993, HMSO, London).

Home Office, Police Reform. Cm 2281. (1998, HMSO, London).

Ingrid Posen, The Role and Responsibilities of the Police. (1996, Police Foundation / Policy Studies Institute, London).

Home Office, Policing a New Century: A Blue-print for Reform. Cm 5326. (2001, TSO, London).

Home Office, Policing: Building Safer Communities Together. (2001, Home Office. London).

Home Office, One Step Ahead: A 21st Strategy to Defeat Organised Crime. Cm 6167. (2004, TSO, London).

Home Office, Building Communities, Beating Crime: a Better Police Service for the 21st Century. Cm 6360. (2004, TSO, London).

Her Majesty's Inspectorate of Constabulary, Closing the Gap: A Review of the 'Fitness for Purpose' of the Current Structure of Policing in England and Wales. (2005, HMIC, London).

Home Affairs Committee, Police Reform. HC Paper 370, Fourth Report of Session 2004-5. (2005, TSO, London).

Home Affairs Committee, Police Funding. HC Paper 553, Fourth Report of Session 2006-7. (2007, TSO, London).

Sir Ronnie Flanagan, The Review of Policing: Final Report. (2008, Review of Policing, London).

Home Office, From the Neighbourhood to the National: Policing our Communities Together. $\mathrm{Cm}$ 7448. (2008, TSO, London).

Home Affairs Committee, Policing in the $21^{\text {st }}$ Century HC Paper 363, Seventh Report of Session 20078. (2008, TSO, London). 
Policing provision has become increasingly pluralized; a trend set to continue. ${ }^{20}$ 'Softer' service and regulatory functions once performed by the police are now undertaken by local authorities or, increasingly, sub-contracted private providers on behalf of local authorities leaving the police with 'harder' (often confrontational and coercive) functions focused on criminal law enforcement. The relationship between community and police inevitably is changing not least because of the political head-line grabbing expansion of criminalization. A service, part of whose function was to investigate crime, increasingly is seen as a force that enforces criminal law. Not all of Tony Blair's 3,000 new crimes will be policed by the police, but the public will not draw the distinction. ${ }^{21}$ Popular perception will be of a police force invested with yet more powers and opportunities to regulate personal lives.

Just as extra offences have helped reshape policing so, too, private security patrolling of public spaces (e.g. shopping centres, residential estates) and increased use of CCTV have helped to redefine policing and who does it, in turn raising questions about how new policing provision engages with human rights and the related, although distinct, issues of accountability and governance. ${ }^{22}$ Continual surveillance through techniques such as CCTV for example, even though it is asserted to be benign and for the protection of the community, and even though human rights are protected in principle and in law, undermines human rights simply through the relentless invasion of individual privacy. ${ }^{23}$ Thus at the same time as human rights are being redefined, policing, too, is subject to varied and evolving meaning.

\footnotetext{
20 Trevor Jones and Tim Newburn (eds), Plural Policing: A Comparative Perspective (2006, Routledge, London).

21 Kirsty Walker, '3000 new offences created since Tony Blair came to power' The Daily Mail $16^{\text {th }}$ August 2006, accessible at www.dailymail.co.uk/news/article-400939/3-000-new-criminal-offencescreated-Tony-Blair-camepower.html (accessed 22 May 2009); Channel 4 News 'Has Labour really created 3000 new crimes?' Channel 4 News $19^{\text {th }}$ September 2006, accessible at http://www.channel4.com/news/articles/world/has\%20labour\%20really\%20created\%203000\%20new\% 20crimes/169245 (accessed 19 November 2008).

22 Trevor Jones and Tim Newburn, Private Security and Public Policing. (1998, Clarendon Press, Oxford); Robert Davis, Christopher Ortiz, Sarah Dadush, Jenny Irish, Arturo Alvarado and Diane Davis, 'The public accountability of private police: lessons from New York, Johannesburg and Mexico City.' (2003) 13 Policing \& Society 197; Andrew Crawford and Stuart Lister. 'Additional security patrols in residential areas: notes from the marketplace.' (2006) 16 Policing \& Society 164; Julie Ayling, Peter Grabosky and Clifford Shearing, Lengthening the Arm of the Law: Enhancing Police Resources in the Twenty-First Century (2009, Cambridge University Press, Cambridge).

${ }^{23}$ Home Affairs Committee, A Surveillance Society? HC Paper 1122, Second Special Report of Session 2007-8. (2008, TSO, London).
} 


\section{The prevailing political discourse}

Part of that varied and evolving meaning is evident from the blurring of the edges between policing and state security objectives and functions in a post 9/11 world in which political discourse is heavily coloured by the 'war on terrorism'. ${ }^{24}$ The label 'policing' now encompasses a variety of functions across a continuum from community safety to national security. ${ }^{25}$ Within that continuum agency roles once discrete now overlap.

This mirrors evolving notions in relation to thinking about the policing of organised crime, increasingly reconfigured as a national security threat requiring policing beyond the scope of traditional police agencies. ${ }^{26}$ The Serious Organised Crime Agency [SOCA], established to reduce the harm to the UK arising from national and transnational organised crime, is identified by the government as a critical element of the enhanced national security infrastructure. ${ }^{27}$ SOCA personnel have been recruited from the police, customs, immigration and security services. ${ }^{28}$

As the concept of national security is stretched from the traditional 'Cold War' construction to accommodate transnational organised crime, so another aspect of national security is subject to widening definition. The global 'war on terror' being led by established and functioning 'Western' liberal democracies posits terrorism as a national security threat. Here, the geopolitical context blurs the conceptual definition. Whether non-state actors who engage in terrorism could bring down an established

\footnotetext{
${ }^{24}$ Bradley Bamford, 'The United Kingdom's 'war against terrorism', (2004) 16 Terrorism and Political Violence 737; Mark Finnane 2008). 'The public rhetorics of policing in times of war and violence: conjuring apocalyptic visions', (2008) 50 Crime Law and Social Change 7.

25 William Stuntz, 'Local policing after the terror.' (2001-2002) 111 Yale Law Journey 2137; JeanPaul Brodeur,. 'High and low policing in post 9/11 times.' (2007) 1 Policing: A Journal of Policy and Practice 25; Peter Grabosky, 'Community policing in an age of terrorism.' (2008) 50 Crime Law and Social Change 1

26 Mark Findlay,. 'International rights and Australian adaptations: recent developments in criminal investigation.' (1995) 17 Sydney Law Review 1278; see also Clive Harfield, 'The organization of 'organized crime policing' and its international context.'(2008) 8 Criminology and Criminal Justice 433; also Clive Harfield, 'Paradigms, pathologies, and practicalities - policing organised crime in England and Wales.' (2008) 2 Policing: A Journal of Policy and Practice 63.

27 Cabinet Office. The National Security Strategy of the United Kingdom: security in an interdependent world. (2008, TSO, London).

28 Clive Harfield, (2006). 'SOCA: a paradigm shift in British policing.' (2006) 46 British Journal of Criminology 743 .
} 
democracy through terrorist attacks is debatable. ${ }^{29}$ States least vulnerable to terrorism are those resorting to ever-more draconian powers to 'fight' the phenomenon.

Terrorist attacks in stable jurisdictions cause death and disruption and are undeniably a threat to public order, historically the preserve of criminal law enforcement in liberal democracies. The scale of the September 2001 attack in New York was such that the international community (notably the UN and NATO) declared it an act of war justifying a military rather than a criminal law enforcement response, ${ }^{30}$ thus blurring historical distinctions between the two still further. What is not in doubt is that political responses to the perceived threat have resulted in extensive criminal law enforcement legislation with an impact on human rights and the practice of policing. ${ }^{31}$ Policing, historically regarded as being for the purposes of preserving public order and reactive criminal investigation, is increasingly required to be preventative or even pre-emptive (for example, in the use of Control Orders in the UK or Preventative Detention Orders in Australia). In this sense terrorism is changing the nature of democracy and the relationship between human rights protection and policing even in those states the socio-political stability of which reinforces their resistance to the breakdown of democratic government. And the wider context for this is a world in which rights conceptualisation has assumed a life of its own. Rules 'intended to constrain others' are now applied to the rule-makers: for some, this is 'politically inconvenient'. ${ }^{32}$

At a practical and organizational level responses have placed increased emphasis on partnership between different agencies within the same profession (police-to-police co-operation) and from different professions (police alongside

\footnotetext{
${ }^{29}$ It can be argued that the protagonists from both sectarian communities in Northern Ireland are now achieving more of their objectives through the democratic process than they achieved in thirty years of terrorism.

30 Steiner et al, above n 7, 380.

31 Viet Dinh, 'Freedom and security after September 11.' (2002) 25 Harvard Journal of Law and Public Policy 399; Helen Fenwick, 'The Anti-Terrorism, Crime and Security Act 2001: a proportionate response to 11 September?' (2002) 65 Modern Law Review 724; Heymann above n 10; Rogelio Alonso and Fernando Reinares 'Terrorism, human rights and law enforcement in Spain.' (2005) 17 Terrorism and Political Violence 265; Garry Hindle, 'Policing terrorism in the UK.'(2007) 1 Policing: A Journal of Policy and Practice 38; M. O'Neill, 'A critical analysis of the EU legal provisions on terrorism.'(2008) 20 Terrorism and Political Violence 26.

32 Philippe Sands, Lawless World: Making and Breaking Global Rules. (2008, Penguin Books, London) xi.
} 
intelligence and national security agencies) ${ }^{33}$ in which different understandings of human rights prevail; this is a further potential source of confusion. ${ }^{34}$

The true nature of the nexus between terrorism and organised crime is much debated. ${ }^{35}$ The debate is significant in terms of policing and human rights because from it arises the question whether special measures deemed necessary to prevent terrorism could also be appropriate for the policing of organised crime (particularly if it can be linked to terrorism), hitherto policed according to the criminal law model rather than the 'war on terror' model. ${ }^{36}$ The extraordinary (but, exceptionally, necessary) would then become ordinary. Intrusive, rights-breaching investigation and preventative measures politically justified on the basis of the nature and potential scale of the terrorist threat then seem justifiable through extension of the rhetoric about organised crime harm. ${ }^{37}$

From this rhetoric arise problems of interpreting proportionality because of potential confusion between what may be argued as proportionate in political terms and what is proportionate in legal terms. ${ }^{38}$ The HRA establishes tests for the legitimacy, necessity and proportionality of proposed investigative tactics. ${ }^{39}$ Special measures such as detention without charge may be argued as a politically proportionate response to a perceived threat and the potential scale of harm (in which, in the confused rhetoric, the acts of war of $9 / 11$ are now the criminal law enforcement legislative benchmark). There is no precision and considerable breadth of interpretation here. By contrast, when planning the use of intrusive investigation

\footnotetext{
33 Dame Eliza Manningham-Buller, 'Partnership and continuous improvement in countering twentyfirst century terrorism.' (2007) 1 Policing: A Journal of Policy and Practice 43.

${ }^{34}$ Clive Harfield, above n 29, 755.

35 For a flavour of the debate see Emma Björnehed, 'Narco-terrorism: the merger of the war on drugs and the war on terror.' (2004) 6 Global Crime 305; Tamara Makarenko, 'The crime-terror continuum: tracing the interplay between transnational organised crime and terrorism' (2004) 6 Global Crime 129; Northern Ireland Affairs Committee. Organised Crime in Northern Ireland. (2006, TSO, London); J. Picarelli, 'The turbulent nexus of transnational organised crime and terrorism: a theory of malevolent international relations.' (2006) 7 Global Crime 1; Thomaz Costa and Gastón Schulmeister. 'The puzzle of the Iguazu tri-border area: many questions and few answers regarding organised crime and terrorism links.' (2007) 8 Global Crime 26; Ryan Clarke and Stuart Lee. 'The PIRA, D-Company and the crimeterror nexus.' (2008) 20 Terrorism and Political Violence 376; Michael Stohl. 'Networks, terrorists and criminals: the implications for community policing.' (2008) 50 Crime Law and Social Change 59.

${ }^{36}$ Steiner et al, above $\mathrm{n} 7,383$.

37 See Andrew Ashworth, Human Rights, Serious Crime and Criminal Procedure. (2002, Sweet \& Maxwell, London) 105, and 107-8.

${ }^{38}$ Fenwick above n 33; Conor Gearty, '11 September 2001, counter-terrorism, and the Human Rights Act.' (2005) 32 Journal of Law and Society 18.

39 Nick Taylor, 'Covert policing and proportionality.' [2006] Covert Policing Review 22. Clive Harfield, and Karen Harfield, Covert Investigation. (2008, $2^{\text {nd }}$ edn, Oxford University Press, Oxford) 17-20.
} 
methods within the context of the HRA and the associated Regulation of Investigatory Powers Act 2000 [RIPA], it is not the seriousness of the (potential) offence or the extent of the (potential) harm that is at issue but whether the use of specific coercive and intrusive methods are proportionate to the evidential product derived therefrom. ${ }^{40}$ It is a more precise consideration that investigators applying for and senior officers authorising intrusive investigation must be careful to divorce from the wider political context. Prevention of uncertain future events and the investigation of completed crimes, both of which are the responsibility of the police, present police managers with a strained dichotomy in which the consideration of any given act that may breach a statutory human right must take place in very different contexts.

\section{The management of covert investigation}

The prevailing context of human rights and policing within which English police managers operate is fluid. What remains fixed, however, is the statutory governance framework within which policing, particularly covert investigation, functions. The Regulation of Investigatory Powers Act 2000 regulates surveillance whilst the Police Act 1997 (enacted in anticipation of the HRA and in response to Strasbourg case-law) governs interference with property pursuant to the conducting of surveillance.

Authorisation of covert investigation methods in England is a non-judicial function in which the degree of intrusiveness dictates the level of authorisation required. ${ }^{41}$ The majority of covert investigation activity is self-authorised by police and customs officers with senior managerial rank under whose command the individual investigation managers operate. Judicial scrutiny occurs only if the lawfulness of such authorities is challenged in the trial process. ${ }^{42}$ The power of

\footnotetext{
40 David Ormerod, 'Recent developments in entrapment.' [2006] Covert Policing Review 65, 77-8; Taylor above $n$ 41, 26.

${ }^{41}$ Interception of communications, considered to be the most intrusive form of investigation, currently can only be authorised by the Home Secretary. Covert surveillance undertaken on residential premises or in private vehicles and which involves either the presence of an individual or the use of a surveillance device on the premises or in the vehicle can be authorised by a chief police officer subject to the prior approval of the Office of Surveillance Commissioners. Other forms of surveillance falling outside these categories can be authorised by Superintendents (see Harfield and Harfield above $n$ 41).

42 Andrea Hopkins, 'Testing lawfulness: the authorisation of interception of communications and covert surveillance under the Regulation of Investigatory Powers Act 2000.' [2005] Covert Policing Review: 33; David Ormerod and Adrian Waterman, 'Abusing a stay for Grant?' [2005] Covert Policing Review 5.
} 
investigators to self-authorise breaches of human rights is not uncontroversial, with a strong body of opinion in favour of surveillance only where authorised by judicial warrant, although such a development would seem to change fundamentally the relationship of the English judiciary to pre-trial investigation. ${ }^{43}$

If the principle of self-authorisation is controversial amongst civil libertarians, the mechanics are equally controversial amongst investigators. Senior managers' consideration of whether to authorise investigation that breaches a statutory right has been translated into an application and authorisation process which, whether it is paper-based or electronic, has been widely criticised by investigators as bureaucratically onerous. The Home Office has responded by arguing that investigators have misinterpreted the process in such a way as to make it overly bureaucratic. $^{44}$ Investigators are inclined to regard the application and authorisation process merely as impedimentary hoops to jump through; civil libertarians regard the process as an inadequate substitute for proper, independent review.

The extent to which self-authorisation is a suitable mechanism depends on the preparation done by investigators. Preparation takes two forms. The Chief Surveillance Commissioner, whose role it is to inspect for and audit legislative compliance amongst those authorities empowered to undertake surveillance pursuant to their functions, has on an annual basis since 2001 criticised the inadequacy of training in relation to RIPA for applicants and authorising officers. ${ }^{45}$ The criticisms are valid for the police service; they are equally valid for those authorities, such as local government bodies, whose use of covert investigation does not benefit from the same high frequency of use and experience as investigative and criminal law enforcement agencies. ${ }^{46}$ Misuse of covert investigation powers by non-police authorities has prompted government reflection and public consultation about whether such authorities should remain invested with such powers. ${ }^{47}$

\footnotetext{
${ }^{43}$ Harfield and Harfield above n 41, 10-13.

44 Sir Ronnie Flanagan,. The Review of Policing: Final Report. (2008, Review of Policing, London); Harfield and Harfield above n 41, 13-4. See also the Chief Surveillance Commissioner's Annual Reports for 2003-4, (in which the then Chief Commissioner expressed some sympathy for investigators) and for 2006-7 (in which the Chief Commissioner criticised investigators for 'unnecessary repetition and verbosity': Para 12.1).

${ }^{45}$ As part of an ongoing review of RIPA and its implementation, government is reviewing whether all of the 900 or so public authorities (besides the 43 police forces in England and Wales) originally empowered to use RIPA powers do in fact need to have such powers.

46 Harfield and Harfield above n 41, 22.

${ }^{47}$ Home Office, Regulation of Investigatory Powers Act 2000: Consolidating Orders and Codes of Practice - a Public Consultation Paper (2009, Home Office, London).
} 
Perversely, training may actually reinforce the second inherent deficiency. It is proposed here that there is a qualitative difference between training for a specific task and education for a role. Investment in police personnel tends to default to the former and, in the author's personal experience as an operational police officer, RIPAtraining in the police service initially comprised mainly and merely instruction on how to complete the necessary paper or electronic forms, thus reinforcing the perception amongst colleagues that human rights compliance was a bureaucratic process. Training in form-filling was prioritised over education about the new investigatory powers law. ${ }^{48}$ Consequently human rights have been presented as a procedure to be followed rather than a paradigm to be cultivated, adopted and practised, underpinning all aspects of policing and forming part of its very rationale.

\section{Conclusion: the cultural challenge}

It has been argued that legislated rights, whilst generating increased activity for government officials and lawyers, do not necessarily nourish a culture that provides enhanced rights protection for the community whilst simultaneously stimulating dialogue between community and professionals. ${ }^{49}$ In England, the framework for ensuring demonstrable compliance with the principles of legality, proportionality and necessity, rendering self-authorisation amenable to subsequent external inspection and audit, has come to be viewed as representative of bureaucracy impeding practical policing rather than with a culture of human rights that underpins the legitimacy of robust criminal investigation. ${ }^{50}$ There is not a little irony in the

\footnotetext{
48 On transferring from the National Crime Squad to Warwickshire Police it was suggested by Warwickshire Police to the author that, on the basis of his familiarity with covert investigation law through his work on the NCS that he could assist the force by writing a RIPA training programme and touring the force to deliver the training via informal workshops. This proposed activity was to be in addition to the author's posted duties of running both an intelligence department and a covert operations unit. The author argued, eventually successfully, that the force training department should devise and deliver formal training in the law. The episode is indicative of the attitude towards training for RIPA that initially prevailed.

49 Joo-Cheng Tham and Keith Ewing 'Limitations of a charter of rights in the age of counterterrorism.' [2007] Melbourne University Law Review 31.

50 David Davis, 'Tories have best response to this emergency' The Daily Telegraph $15^{\text {th }}$ December 2008, accessible at http://www.telegraph.co.uk/comment/personal-view/3554490/Tories-have-bestresponse-to-this-emergency.html (accessed 22 May 2009); John Lettice, 'Top cop urges RIPA review in coded attack on snoop code: less bureaucracy, more clarity, more bugging' The Register $8^{\text {th }}$ February 2008, accessible at http://www.theregister.co.uk/2008/02/08/flanagan_ripa/ (accessed 22 May 2008); Gemma Ilsten, 'Home Office announces RIPA consultation' Police Professional 23 April 2009 accessible at http://www.policeprofessional.com/news.aspx?id=8600 (accessed 22 May 2009).
} 
contemplation that due process as currently configured may mechanistically constrain and undermine promulgation of the very values it seeks to protect.

At the same time as the notion of what comprises human rights is expanding, attempts to prevent certain perceived terrorist harms challenges the narrow traditional construction of human rights protection. Similarly, the proper function of policing is subject to vigorous dialogue in which basic policing services are now available from an ever-increasing number of alternative providers whilst traditional instrumental demarcations between community safety and national security/defence functions are breaking down despite the different policy origins and objectives of each. Trying to establish a sustainable organizational culture is a major challenge given this context of significant societal variables. The current compliance framework represents initial coming-to-grips with the issues and implications. The challenge now is achieve an organizational metamorphosis in which human rights are transposed from something imposed on the police to keep them in check to a cultural norm imbued in all aspects of policing. 


\section{Bibliography}

\section{Articles, books and reports}

Alonso, Rogelio and Reinares, Fernando (2005). 'Terrorism, human rights and law enforcement in Spain.' 17 Terrorism and Political Violence 265.

Ashworth, Andrew. Human Rights, Serious Crime and Criminal Procedure. (2002, Sweet \& Maxwell, London).

Ayling, Julie., Grabosky, Peter and Shearing, Clifford. Lengthening the Arm of the Law: Enhancing Police Resources in the Twenty-First Century (2009, Cambridge University Press, Cambridge).

Bamford, Bradley. 'The United Kingdom's 'war against terrorism'.' (2004). 16 Terrorism and Political Violence 737.

Bennett, Alan. The History Boys. (2004, Faber, London).

Billingsley, Roger. 'Duty of care for informers.' (2005). 78 The Police Journal 209.

Björnehed, Emma. 'Narco-terrorism: the merger of the war on drugs and the war on terror.' (2004). 6 Global Crime 305.

Brodeur, Jean-Paul. 'High and low policing in post 9/11 times.' (2007). 1 Policing: A Journal of Policy and Practice 25.

Cabinet Office. The National Security Strategy of the United Kingdom: security in an interdependent world. (2008, TSO, London).

Channel 4 News 'Has Labour really created 3000 new crimes?' Channel 4 News $19^{\text {th }}$ September 2006, accessible at http://www.channel4.com/news/articles/world/has\%20labour\%20really\%20cr eated\%203000\%20new\%20crimes/169245 (accessed $19^{\text {th }}$ November 2008).

Chong, Agnes and Kadous, Waleed. 'Freedom for security: necessary evil or Faustian pact?' (2005). 28 UNSW Law Journal 887.

Clarke, Ryan. and Lee, Stuart. 'The PIRA, D-Company and the crime-terror nexus.' (2008). 20 Terrorism and Political Violence 376.

Costa, Thomaz. and Schulmeister, Gastón 'The puzzle of the Iguazu tri-border area: many questions and few answers regarding organised crime and terrorism links.' (2007). 8 Global Crime 26.

Public Space: The Journal of Law and Social Justice (2009) Vol 4, pp 91-112 
Crawford, Andrew and Lister, Stuart. 'Additional security patrols in residential areas: notes from the marketplace.' (2006). 16 Policing \& Society 164.

Davis, David. 'Tories have best response to this emergency' The Daily Telegraph $15^{\text {th }}$ December 2008, accessible at http://www.telegraph.co.uk/comment/personalview/3554490/Tories-have-best-response-to-this-emergency.html (accessed 22 May 2009)

Davis, Robert; Ortiz, Christopher; Dadush, Sarah; Irish, Jenny; Alvarado, Arturo and Davis, Diane. 'The public accountability of private police: lessons from New York, Johannesburg and Mexico City.' (2003). 13 Policing \& Society 197.

Dinh, Viet. 'Freedom and security after September 11.' (2002). 25 Harvard Journal of Law and Public Policy 399.

Dixon, David. Law in Policing: Legal Regulation and Police Practices. (1997, Clarendon Press, Oxford).

Fenwick, Helen. 'The Anti-Terrorism, Crime and Security Act 2001: a proportionate response to 11 September?' (2002). 65 Modern Law Review 724.

Findlay, Mark. 'International rights and Australian adaptations: recent developments in criminal investigation.' (1995). 17 Sydney Law Review 278

Finnane, Mark. 'The public rhetorics of policing in times of war and violence: conjuring apocalyptic visions.' (2008). 50 Crime Law and Social Change 7.

Flanagan, Sir Ronnie. The Review of Policing: Final Report. (2008, Review of Policing, London).

Fredman, Sandra. Human Rights Transformed: Positive Rights and Positive Duties. (2008, Oxford University Press, Oxford).

Gearty, Conor. '11 September 2001, counter-terrorism, and the Human Rights Act.' (2005). 32 Journal of Law and Society 18.

Grabosky, Peter. 'Private sponsorship of public policing.' (2007). 8 Police Practice and Research 5.

Grabosky, Peter. 'Community policing in an age of terrorism.' (2008). 50 Crime Law and Social Change 1.

Grieve, John, Harfield, Clive and MacVean, Allyson. Policing. (2007, Sage, London). 
Harfield, Clive. 'Consent, consensus or the management of dissent?: challenges to community consultation in a new policing environment.' (1997).7 Policing and Society 271.

Harfield, Clive. 'SOCA: a paradigm shift in British policing.' (2006). 46 British Journal of Criminology 743.

Harfield, Clive. 'The organization of 'organized crime policing' and its international context.' (2008). 8 Criminology and Criminal Justice 433.

Harfield, Clive. 'Paradigms, pathologies, and practicalities - policing organised crime in England and Wales.' (2008). 2 Policing: A Journal of Policy and Practice 63.

Harfield, Clive and Harfield, Karen Covert Investigation. (2008, 2nd ed, Oxford University Press, Oxford).

Heymann, Philip. 'Civil liberties and human rights in the aftermath of September 11.' (2002). 25 Harvard Journal of Law and Public Policy 441.

Hindle, Garry. 'Policing terrorism in the UK.' (2007). 1 Policing: A Journal of Policy and Practice 38.

Home Affairs Committee Policing in the $21^{\text {st }}$ Century HC Paper 363, Seventh Report of Session 2007-8. (2008, TSO, London).

Home Affairs Committee A Surveillance Society? HC Paper 58, Fifth Report of Session 2007-8. (2008, TSO, London)

Home Office Building Communities, Beating Crime: A Better Police Service for the $21^{\text {st }}$ Century (2004, TSO, London)

Home Office From the Neighbourhood to the National: Policing our Communities Together. (2008, TSO, London).

Home Office Regulation of Investigatory Powers Act 2000: Consolidating Orders and Codes of Practice - a Public Consultation Paper (2009, Home Office, London).

Hopkins, Andrea. 'Testing lawfulness: the authorisation of interception of communications and covert surveillance under the Regulation of Investigatory Powers Act 2000.' [2005]. Covert Policing Review 33. 
Ilsten, Gemma. 'Home Office announces RIPA consultation' Police Professional 23 April 2009 accessible at http://www.policeprofessional.com/news.aspx?id=8600 (accessed 22 May 2008)

Independent Commission on Policing for Northern Ireland A New Beginning: Policing in Northern Ireland. (1999, Independent Commission on Policing for Northern Ireland, Belfast).

Jones, Trevor. 'The governance and accountability of policing' in Newburn, Tim (ed). Handbook of Policing. (2003, Willan, Cullompton) 603.

Jones, Trevor and Newburn, Tim Private Security and Public Policing. (1998, Clarendon Press, Oxford).

Jones, Trevor and Newburn, Tim, (eds) Plural Policing: A Comparative Perspective. (2006, Routledge, London).

Lettice, John. 'Top cop urges RIPA review in coded attack on snoop code: less bureaucracy, more clarity, more bugging' The Register $8^{\text {th }}$ February 2008, accessible at http://www.theregister.co.uk/2008/02/08/flanagan_ripa/ (accessed 22 May 2008)

Loader, Ian and Mulcahy, Aogán, Policing and the Condition of England: memory, Politics and Culture (2003, Oxford University Pres, Oxford).

Makarenko, Tamara. 'The crime-terror continuum: tracing the interplay between transnational organised crime and terrorism.' (2004). 6 Global Crime 129.

Manningham-Buller, Dame Elizabeth. 'Partnership and continuous improvement in countering twenty-first century terrorism.' (2007). 1 Policing: A Journal of Policy and Practice 43.

Newburn, Tim. 'Policing since 1945 ' in Newburn, Tim (ed) Handbook of Policing. (2003, Willan, Cullompton) 84.

Northern Ireland Affairs Committee Organised Crime in Northern Ireland. (2006). TSO, London).

O'Neill, Maria. 'A critical analysis of the EU legal provisions on terrorism.' (2008) 20 Terrorism and Political Violence 26.

Ormerod, David. 'Recent developments in entrapment.' [2006] Covert Policing Review 65.

Public Space: The Journal of Law and Social Justice (2009) Vol 4, pp 91-112 
Ormerod, David and Waterman, Adrian. 'Abusing a stay for Grant?' (2005) Covert Policing Review 5.

Picarelli, John. 'The turbulent nexus of transnational organised crime and terrorism: a theory of malevolent international relations.' (2006). Global Crime 1.

PM Strategy Unit (2007). Building On Progress: Security, Crime and Justice. London, TSO.

Rock, Paul. Constructing Victim's Rights: the Home Office, New Labour and Victims. (2004, Oxford University Press, Oxford).

Sands, Philippe. Lawless World: Making and Breaking Global Rules. (2006, Penguin Books, London).

Savage, Steve. Police Reform: Forces for Change. (2007, Oxford University Press, Oxford).

Sedley, Sir Stephen.. 'The rocks or the open sea: where is the Human Rights Act heading.' (2005). 32 Journal of Law and Society 3.

Steiner, Henry; Alston, Philip and Goodman, Ryan. International Human Rights in Context: Law, Politics, Morals. (2008, Oxford University Press, Oxford).

Stohl, Michael. 'Networks, terrorists and criminals: the implications for community policing.' (2008). 50 Crime Law and Social Change 59.

Stuntz, William. 'Local policing after the terror.' (2001-2002). 111 Yale Law Journey 2137.

Taylor, Nick. 'Covert policing and proportionality.' (2006). Covert Policing Review 22.

Tham, Joo-Cheng. and Ewing, Keith. 'Limitations of a charter of rights in the age of counter-terrorism.' (2007). 31 Melbourne University Law Review 462.

Waddington, Peter. 'Political axe hangs over policing.' Police Review. $\left(24^{\text {th }}\right.$ October 2008, Janes London), 16.

Walker, Kirsty. '3000 new offences created since Tony Blair came to power' The Daily Mail $16^{\text {th }}$ August 2006, accessible at www.dailymail.co.uk/news/article400939/3-000-new-criminal-offences-created-Tony-Blair-camepower.html (accessed 22 May 2009) 
Weinberg, Leonard; Eubank, William and Francis, Elizabeth. 'The cost of terrorism: the relationship between international terrorism and democratic governance.' (2008). 20 Terrorism and Political Violence 257.

\section{Legislation}

Police Act 1997 (UK) c 50

Human Rights Act 1998 (UK) c 42

Regulation of Investigatory Powers Act 2000 (UK) c 23

\section{Treaties}

European Convention on Human Rights and Fundamental Freedoms, opened for signature 4 November 1950, ETS 5, (entered into force 3 September 1953). 